Brazilian Journal of Microbiology (2009) 40: 563-568

ISSN 1517-8382

\title{
BIOTRANSFORMATION OF A CAGE-LIKE DIELS-ALDER ADDUCT AND DERIVATIVES BY MUCOR RAMOSISSIMUS SAMUTSEVITSCH
}

\section{Felicia Megumi Ito ${ }^{1}$; Ana Elisa Maciel Mena'; Maria Rita Marques²; Dênis Pires de Lima ${ }^{1}$; Adilson Beatriz ${ }^{1 *}$}

${ }^{1}$ Departamento de Química, Centro de Ciências Exatas e Tecnologia, Universidade Federal de Mato Grosso do Sul, Campo Grande, MS, Brasil; ${ }^{2}$ Departamento de Morfofisiologia, Centro de Ciências Biológicas e da Saúde, Universidade Federal de Mato Grosso do Sul, Campo Grande, MS, Brasil.

Submitted: October 22, 2008; Returned to authors for corrections: December 19, 2008; Approved: May 04, 2009.

\begin{abstract}
The present study aimed to evaluate the ability for biotransformation of the Diels-Alder adduct tricyclo[6.2.1.0 $\left.0^{2,7}\right]$ undeca-4,9-dien-3,6-dione (1) and two synthetic derivatives by the saprobe fungus Mucor ramosissimus Samutsevitsch. Products from oxidation, isomerization and, regioselective and enantioselective reduction were achieved.
\end{abstract}

Key words: Mucor ramosissimus, biotransformation, Diels-Alder adduct

\section{INTRODUCTION}

The use of microorganisms in chemistry is not new, although it has assumed renewed emphasis in recent years. Biocatalytic processes for the synthesis of chemicals of industrial value have been attracting much attention as an environmental-friendly procedure (5). Bacteria and fungi have been used to produce chemicals, pharmaceuticals and perfumes during recent years (1). Whole microbial cells play an important role in organic synthesis field because of their diversity. Several microorganisms with unique catalytic abilities have been found by intensive screening and put to practical use (5). Moreover, the biotransformation may lead to substitution at chemically inaccessible sites without perturbing the underlying carbon skeleton of the substrate (2). However, considering the great availability of useful microorganisms and the reactions that they can catalyze, the use of this strategy by industry is still modest (1). Therefore, the description of new useful reactions promoted by microbes is of great academic and industrial interest.

Mucor ramosissimus Samutsevitsch, a filamentous zygomycete, is commonly found in soil, litter, or on plant surfaces (9). Our group is interested in testing the ability this saprobic fungus to perform bioconversions of natural or organic synthetic compounds. Those could be a source of

*Corresponding Author. Mailing address: Departamento de Química, CCET/UFMS. Av. Senador Filinto Müller, 1555, Vila Ipiranga - CEP 79074-460, Campo Grande, MS, Brazil.; Tel.: (67) 3345-3676, FAX: (67) 3345-3552.; E-mail: adilbeat@nin.ufms.br 
optically active intermediates and precursors of chiral compounds or chiral auxiliaries for asymmetric synthesis. We initially focused our attention to the synthesis of potentially bioactive compounds from the Diels-Alder adduct 1 (endotricyclo[6.2.1.0 2,7$]$ undeca-4,9-dien-3,6-dione) (Fig. 1). Nowadays, there is an increasing interest on this structural framework to study biological activity of cage-like rigid polycyclic molecules since their topological peculiarities may interact through a specific way with bioreceptors (6). Besides, the chiral alcohol 3 (derivative of adduct 1) can be employed for preparation of optically active 4hydroxycyclohex-2-en-1-one, which is a starting material for the synthesis of members of the compactin-mevinolin family of antihypercholesterolemic natural products (7).

We therefore herein report the results of the biotransformation tests carried out with the dienedione 1 and two synthetic derivatives ( 2 and 3 ) in liquid culture medium of $M$. ramosissimus.

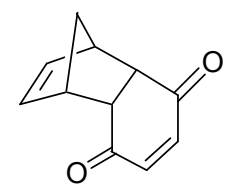

1

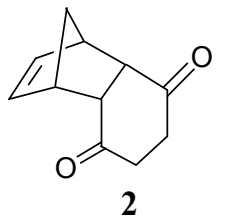

2

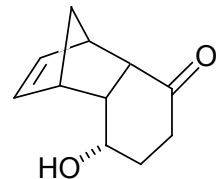

$( \pm)-3$
Figure 1. Chemical structures of Diels-Alder adduct 1 and synthetic derivatives 2 and 3 .

\section{MATERIALS AND METHODS}

The compounds 1, 2 and $( \pm)-3$ were readily prepared as reported in our previous paper (6). ${ }^{1} \mathrm{H}$ and ${ }^{13} \mathrm{C}$ spectra were determined at 300 and $75 \mathrm{MHz}$ respectively. TLC was performed on Merck $60 \mathrm{~F}_{254}$ precoated silica plates and spots were detected by spraying with a solution of $0.1 \%$ solution of vaniline in sulfuric acid/methanol/water (1:4.5:4.5) followed by charring. Column chromatography was performed with Si60 (Acros, 70-230 mesh).

Culture of Mucor ramosissimus Samutsevitsch was donated by Dra. Sônia M. de Campos Dietrich (IBT - São Paulo). Stock culture was maintained on potato dextrose agar (PDA, Merck) under refrigeration. Culture of $M$. ramosissimus was precultivated in Petri dishes on PDA solid medium at $22{ }^{\circ} \mathrm{C}$ in darkness for 8 days (9). Small fragments of this agar were transferred to previously autoclaved conical flasks of $250 \mathrm{~mL}$ containing culture made of D-glucose (4.0 $\mathrm{g})$, asparagine $(0.2 \mathrm{~g})$, monobasic potassium phosphate $(0.05$ $\mathrm{g})$, magnesium sulfate $(0.025 \mathrm{~g})$, thiamine $(0.05 \mathrm{~g})$ dissolved in $100 \mathrm{~mL}$ of distilled water. The $\mathrm{pH}$ was adjusted to 6.0 with an aqueous solution of $\mathrm{NaOH} \quad 0.1 \mathrm{~mol} / \mathrm{L}$. For biotransformation, the microorganism was cultivated in an orbital shaker at $30{ }^{\circ} \mathrm{C}$ and $150 \mathrm{rpm}$ in $250 \mathrm{~mL}$ conical flasks containing $200 \mathrm{~mL}$ of aqueous medium. The $\mathrm{pH}$ was adjusted as previously mentioned. After $48 \mathrm{~h}, 1.15 \mathrm{mmol}$ of substrate dissolved in ethanol $(0.5 \mathrm{~mL})$ was added. Everyday, starting $24 \mathrm{~h}$ after substrate addition, samples were taken and analyzed by TLC. Culture medium and mycelia were both separated by filtration (celite) and extracted with ethyl acetate (x3). The solvent was evaporated and the crude extract separated on Si-60 column with hexane-ethyl acetate (2:1). Suspension of spores was obtained by washing culture of $M$. ramosissimus with distilled water. The spores were then extracted, filtered with sterilized water and counted in a Neubauer chamber. The concentrations were adjusted to $10^{6}$, $10^{4}$ and $10^{2}$ spores $/ \mathrm{mL}(8)$. Spores of known concentrations $(1 \mathrm{~mL})$ were added to $100 \mathrm{~mL}$ of culture medium and placed in an orbital shaker at $150 \mathrm{rpm}$. After 48 hours, enedione 2 $(100 \mathrm{mg})$ was added to the medium and the reaction was monitored each 24 hours, during 20 days. 


\section{RESULTS AND DISCUSSION}

The biotransformations performed by Mucor ramosissimus yields products of reduction, oxidation, isomerization and, regioselective and enantioselective reduction were achieved (See Table 1). The structures of compounds 1-5 were confirmed by the spectroscopic means comprising ${ }^{1} \mathrm{H}$ and ${ }^{13} \mathrm{C}$ NMR together with comparison with the literature $(6,7)$.

The formation of product 4 could be a result of a simple isomerization of 1 , due to the action of a base in the culture medium. According to theoretical study on free energies of enzyme-catalyzed $\beta$-elimination reaction carried out by Gerlt and Gassman $(4,12)$, we can rationalize this mechanism as being a concerted general acid-base catalysis as shown in Scheme 1 .

Table 1. Results of bioconversion of compounds 1-3 by M. ramosissimus

Compound Conversion*

* Percentage of starting material conversion. 
Scheme 1.
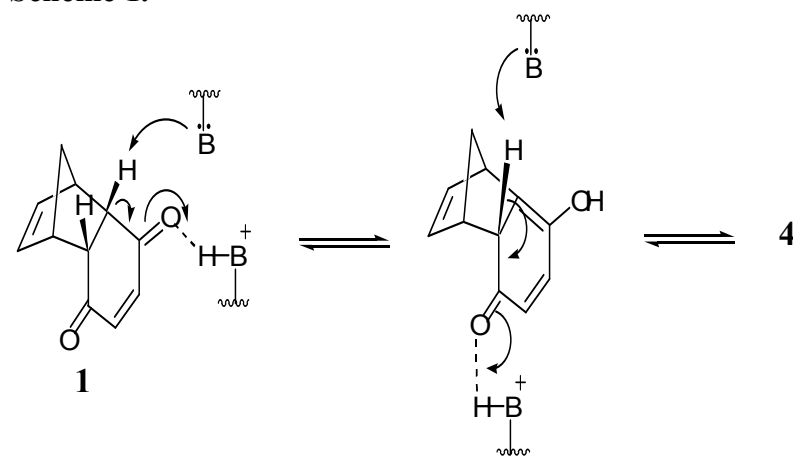

In order to account for the reduction of 1 leading to product 2, one may address to an 1,4-addition of hydride with subsequent proton removal from the mixture $(3,4)$. Frequently, enzymes NADH-dependent enolate reductases are involved in this type of process and they are found in many microorganisms (3).

Microbial transformation of diketone 2 resulted in a diastereoisomeric mixture of the alcohols 3 and 5 (75:25). The stereoisomers 3 and 5 could not be separated by flash chromatography. However, it was possible to identify the signals on ${ }^{1} \mathrm{H}$ and ${ }^{13} \mathrm{C}$ NMR spectra for each compound and compare them to literature data (7). The isomeric ratio was determined by integration of signals in the ${ }^{1} \mathrm{H}$ NMR spectrum of the mixture. Biocatalytic reductions of ketones can be carried out with whole-cell system or isolated enzymes. Often the enzyme involved in these transformations is a ketoredutase/dehydrogenase NADPH-dependent $(10,13)$ and this bioconversions result in high enantioselectivity $(11,13$, 14). The mixture of alcohols 3 and 5 presented optical activity $\left([\alpha]_{\mathrm{D}}{ }^{20}=-31.04\right.$, c $\left.0.06, \mathrm{MeOH}\right)$, indicating an enantionselective biotransformation.

Marchand et al. (7) had already obtained 3 and 5 from 2 using Saccharomyces cerevisiae culture in similar proportion $(80: 20)$, though, with a opposite optical activity $\left([\alpha]_{\mathrm{D}}^{25}=+\right.$
52,$4 ;$ c. $1,4, \mathrm{CH}_{2} \mathrm{Cl}_{2}$ ) and, the absolute configuration of compound $(+)-3$ was characterized by X-ray diffraction. Therefore, the alcohol (+)-3 presented $S$ configuration at C-6 (Fig. 2), showing in this case a Prelog specificity ( $S$-alcohols) (7).

Conversely, in our hands, using culture of $M$. ramosissimus, compound 3 an opposite absolute configuration implying in a bioreduction following an antiPrelog specificity ( $R$-alcohols).

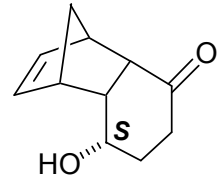

$(+)-3$

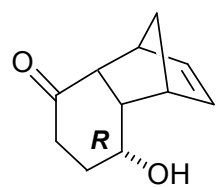

$(-)-3$
Figure 2. Enantiomers of compound 3.

The experiment with the keto-alcohol $( \pm)-3$, produced the diketone 2, which might be accounted by an action of oxidoreductases. The recovered and purified starting material had optical activity $\left([\alpha]_{\mathrm{D}}=+2.5\right.$, c $\left.0.04 \mathrm{CHCl}_{3}\right)$, showing a faster enantionselective biotransformation of the enantiomer oxidation (-)-3 than its antipode.

In order to better scrutinize the transformation on compound 2, experiments to determine the optimum concentration of fungus spores were performed. The obtained results are presented on Table 2 .

As can be observed on Table 2, the best spore concentration result was $10^{4}$ spores $/ \mathrm{mL}$ leading to a yield of $66 \%$ and a higher stereoselectivity. The influence of $\mathrm{pH}$ was anlysed in this concentration and it was found that $\mathrm{pH}=6$ was the optimum for diastereoselectivity. At lower pHs (5 
and 4) and higher (7-9) the stereoselectivity decreased dramatically.

In conclusion, as far as we could search on database systems, this is the first time that $M$. ramosissimus was used for biotransformation of organic synthetic compounds. In every experiment, oxidation and/or reduction products endowed with configurational specificity were achieved what makes the species a promising candidate to carry out future similar studies.

Table 2. Evaluation of the optimum concentration of fungus spores of M. ramosissimus to transform compound 2.

\begin{tabular}{cccccc}
\hline Entry $^{\mathrm{a}}$ & ${\text { [Spores }]^{\mathrm{b}}}^{\text {Time }}$ & $\begin{array}{c}\text { Tims } \\
\text { (days }\end{array}$ & Yields $(\%)$ & Products & {$[\alpha]_{\mathrm{D}}$ (mixture) } \\
\hline 1 & $10^{6}$ & 20 & 67 & $(-)-3+5$ & $-40.3^{\mathrm{o}}$ \\
2 & $10^{4}$ & 20 & 66 & $(-)-3+5$ & $-44.2^{\circ}$ \\
3 & $10^{2}$ & 20 & 59 & $(-)-3+5$ & $-37.3^{\circ}$ \\
\hline
\end{tabular}

${ }^{a}$ Carry out in triplicate. ${ }^{b}$ Spores $/ \mathrm{mL}$

\section{ACKNOWLEDGMENTS}

This work had financial support of FUNDECT-MS (Brazil). The authors thank Dra. Sônia Machado de Campos Dietrich (IBT - São Paulo) for providing M. ramosissimus.

\section{RESUMO}

BIOTRANSFORMAÇÃO DE UM ADUTO DE DIELSALDER CAGE-LIKE E DERIVADOS POR MUCOR RAMOSISSIMUS SAMUTSEVITSCH

Neste trabalho avaliou-se a capacidade de biotransformação do aduto de Diels-Alder triciclo[6.2.1.0 $\left.0^{2,7}\right]$ undeca-4,9-dien-3,6-diona (1) e dois derivados sintéticos pelo fungo sapróbio Mucor ramosissimus Samutsevitsch. Produtos de oxidação, isomerização e redução regiosseletiva e enantiosseletiva foram obtidos.

Palavras-chave: Mucor ramosissimus, biotransformação, aduto de Diels-Alder

\section{REFERENCES}

1. Boaventura, M.A.; Lopes, R.F.A.P.; Takahashi, J.A. (2004). Microorganisms as tools in modern chemistry: the biotransformation of 3-indolylacetonitrile and tryptamine by fungi. Braz. J. Microbiol., $35,345-347$.

2. De Lima, D.P.; Carnell, A.J.; Roberts, S.M. (1999). Microbial transformation of (+)-10 $\beta, 14$-dihydroxy-allo-aromadendrane and (-)allo-aromadendrone. J. Chem. Res. (S), 396-397.

3. Faber, K. (1997). Biotransformation in Organic Chemistry: a textbook. Springer-Verlag, Berlin, $3^{\text {rd }}$ Edition 
Ito, F.M. et al.

4. Gerlt, J.A.; Gassman, P.G. (1992). Understanding Enzyme-Catalyzed Proton Abstraction from Carbon Acids: Details of Stepwise Mechanism for $\beta$-Elimination Reactions. J. Am. Chem. Soc., 114, 5928-5934.

5. Ishige, T.; Honda, K.; Shimizu, S. (2005). Whole Organism Biocatalysis. Curr. Opin. Chem. Biol., 9, 174-180.

6. Ito, F.M.; Petroni, J.M.; Lima, D.P.; Beatriz, A.; Marques, M.R.; Moraes, M.O.; Costa-Lotufo, L.V.; Montenegro, R.C.; Magalhães, H.I.F.; Pessoa, C. (2007). Synthesis and biological evaluation of rigid polycyclic derivatives of the Diels-Alder adduct tricyclo[6.2.1.0 $\left.0^{2,7}\right]$ undeca-4,9-dien-3,6-dione. Molecules, 12, 271-282.

7. Marchand, P.; Xing, D.; Wang, Y.; Bott, S.G. (1995). Improved synthesis of racemic and optically active 4-hydroxycyclohex-2-en-1one. Tetrahedron Asymmetry, 6 (21), 2709-2711.

8. Marques, M.R. (1998). Interação entre uma endopoligalacturonase de Mucor ramosissimus (Mucorales) e a pectina da parede celular de Palicourea marcgravii (Rubiaceae) na indução de respostas de defesa em plantas. São Paulo, Brasil, 149p. (Ph.D. Thesis. Escola Paulista de Medicina. Universidade Federal de São Paulo).

9. Marques, M.R.; Buckeridge, M.S.; Braga, M.R.; Dietrich, S.M.C. (2006). Characterization of an extracellular endopolygalacturonase from the saprobe Mucor ramosissimus Samutsevitsch and its action as trigger of defensive response in tropical plants. Mycopathologia, 162, 337-346.

10. Matsuda, T.; Harada, T.; Nakajima, N.; Nakamura, K. (2000). Mechamism for improving stereoselectivity for asymmetric reduction using acetone powder of microorganism. Tetrahedron Lett., 41, 41354138 .

11. Ni, Y.; Xu, J.H. (2002). Asymmetric reduction of aryl ketones with a new isolate Rhodotorula sp. AS2.2241. J. Mol. Catal. B: Enzym., 18, 233-241

12. Silverman, R.B. (2002). The organic Chemistry of Enzyme-Catalyzed Reaction. Academic Press, London.

13. Yang, W.; Xu, J.H.; Pan, J.; Xu, Y.; Wang, Z.L. (2008). Efficient reduction of aromatic ketones with NADPH regeneration by using crude enzyme form Rhodotorula cells and mannitol as cosubstrate. Biochem. Eng. J., 42 (1), 1-5.

14. Yang, W.; Xu, J.H.; Xie, Y.; Xu, Y.; Zhao, G.; Lin. G.Q. (2006). Asymmetric reduction of ketones by employing Rhodotorula sp. AS2.2241 and synthesis of the $\beta$-blocker (R)-nifelanol. Tetrahedron: Asymmetry, 17 (12), 1769-1774. 